\title{
Non-Destruktive Test Menggunakan NIRS dengan Metode Partial Least Square untuk Bubuk Biji Kakao (dengan Pretreatment Baseline Shift dan Derivatif-2)
}

( Non-Destructive Test by using NIRS with a partial least aquare method to predict fat content of cocoa beans powder (comparissons between baseline shift dan $2^{\text {nd }}$ derivative))

\author{
Desi Nanda Sari ${ }^{1}$, Zulfahrizal $^{1}$, Agus A. Munawar ${ }^{1}$ \\ Program Studi Teknik Pertanian, Fakultas Pertanian, Universitas Syiah Kuala
}

\begin{abstract}
Abstrak.Near Infrared Reflectance Spectroscopy (NIRS) telah menjadi salah satu metode nondestruktif yang paling menjanjikan dan dapat digunakan untuk analisis dalam berbagai bidang, termasuk dibidang pertanian. Kandungan kadar lemak pada biji kakao merupakan komponen termahal dari biji kakao. Tujuan yang ingin dicapai dalam penelitian ini adalah membandingkan data spektrum antar pretreatment baseline shift dan derivatif-2 dalam mengkoreksi spektrum NIRS yang dihasilkan serta mengembangkan metode non-destruktive NIRS dalam menduga kandungan lemak pada bubuk biji kakao. Penelitian ini dilakukan di Laboratorium Instrumentasi dan Energi Program Studi Teknik Pertanian pada bulan Maret sampai Mei 2016. Penelitian menggunakan Baseline Shift dan Derivatif-2 sebagai metode koreksi spektrum dan Partial least Square (PLS) sebagai metode pengolah spektrum. Hasil penelitian yang diperoleh bahwa metode NIRS menggunakan preatreatment baseline shift dan derivatif-2 pada panjang gelombang 2300-2400 $\mathrm{nm}$ merupakan panjang gelombang yang relevan untuk menduga kadar lemak pada bubuk biji kakao. Pendugaan PLS yang didukung pretreatment telah menghasilkan pendugaan yang tergolong good model performance. Pada pendugaan kadar lemak yang sangat baik dalam meningkatkan kinerja PLS pada validasi silang adalah baseline shift.
\end{abstract}

Kata kunci :Biji kakao, NIRS, Kadar lemak, Metode Nondestruktif

Abstract. Near Infrared Reflectance Spectroscopy (NIRS) has become one of the non-destructive method which is the most engagement and can be used to analyze in a variety sectors, including the agriculture sector. The content of the fat content in cocoa beans is one of the most important component than others. The aim of this research was to compare the spectral data between baseline shift and $2^{\text {nd }}$ derivative method in correcting the NIRS spectrum produced and to deloved non-destructive NIRS method in predicting the fat content of cocoa powder. This research is conducted in the Laboratory Instrumentation and Energy of Agriculture Department from March until May 2016. The research uses Baseline Shift and $2^{\text {nd }}$ Derivatives as a method of correction spectrum and Partial least square (PLS) as a regression method. The results of research showed that the NIRS method uses pretreatment baseline shift and $2^{\text {nd }}$ derivative on the wavelength of $2300-2400 \mathrm{~nm}$ is a wavelength that is relevant to estimate fat levels in cocoa beans powder. The estimation of PLS that is supported pretreatment has been resulted the estimation that is included a good performance models. In the estimation of fat content is the best in improving PLS performance on cross-validation is a baseline shift.

Keywords: Cocoa beans, NIRS, levels of fat, non-destructive method

\section{PENDAHULUAN}

International Cocoa Organization (ICCO) menyatakan bahwa Indonesia merupakan produsen biji kakao nomor tiga dunia setelah Pantai Gading dan Ghana. Tahun 2014 produksi biji kakao Pantai Gading diperkirakan sebesar 1.746.000 ton, Ghana 897.000 ton dan Indonesia sebesar 375.000 ton (ICCO, 2015). Sedangkan Aceh sendiri produksi kakao sebesar 34.795 ton. Namun ternyata industri pengolahan kakao dan industri cokelat justru berada di negaranegara Eropa (Belgia, Inggris, dan Swiss), Amerika Serikat, serta Singapura dan Malaysia sehingga nilai tambah tidak dinikmati Indonesia sebagai penghasil biji kakao (BPS, 2013). 
Indonesia perlu menstandarkan biji kakao ekspornya sesuai dengan standar yang dipakai oleh negara-negara industri pengolah kakao. Menurut Mulato et al. (2009), kalangan industri menilai mutu biji kakao tergantung dari tiga aspek yaitu (1) rendemen lemak, (2) kemurnian dan kontaminasi, (3) aroma dan cita rasa. Metode penentuan mutu secara cepat dan tepat diperlukan untuk menghasilkan komoditas kakao standar mutu tinggi yang disyaratkan negara konsumen. SNI menetapkan standar mutu biji kakao dilihat secara fisik seperti kadar air, kontaminasi terhadap serangga, benda asing dan berbagai aroma yang dapat merusak aroma khas kakao (BSN, 2008).Kandungan lemak merupakan komponen termahal dari biji kakao sehingga nilai tersebut dipakai oleh konsumen sebagai salah satu tolak ukur penentuan harga. Kisaran kadar lemak biji kakao Indonesia adalah antara 49\% - 52\% (Mulato, 2009 ; Zulfahrizal, 2014).

Pendeteksian mutu pangan yang cepat dan efisien dapat diwujudkan melalui pengembangan teknologi Near Infrared Reflectance Spectroscopy (NIRS). NIRS telah menjadi salah satu metode non-destruktif yang paling menjanjikan dan dapat digunakan untuk analisis dalam berbagai bidang, termasuk dibidang pertanian. Keuntungan yang dapat diraih adalah persiapan sederhana untuk sampel, proses deteksi cepat, dan ramah lingkungan karena tidak ada bahan kimia yang digunakan.

\section{METODE PENELITIAN}

Penelitian ini dilaksanakan di Laboratorium Instrumentasi dan Energi, Program Studi Teknik Pertanian, Fakultas Pertanian, Universitas Syiah Kuala, Darussalam, Banda Aceh.

\section{Alat dan Bahan}

Alat yang digunakan pada penelitian ini adalah FT-IR IPTEK T-1516, perlengkapan uji kadar lemak, dan unscrambler software ${ }^{\circledR} X$ version 10.1 . Bahan yang digunakan pada adalah bubuk biji kakao dengan jumlah 30 sampel.

\section{Persiapan Bubuk Biji Kakao}

Penelitian ini menggunakan buah kakao varietas lindak yang didapat dari Jember, biji kakao dikeringkan sampai diperoleh biji kakao kering yang layak. Selanjutnya dilakukan penghancuran pada biji kakao dan diayak menggunakan ayakan berukuran 24 mesh untuk mendapatkan ukuran yang seragam yang menghasilkan bubuk biji kakao. Jumlah sampel sebanyak 30 sampel yang terdiri dari 15 sampel non fermentasi dan 15 sampel yang difermentasi, dimana persampel $10 \mathrm{gr}$ dan diletakkan di dalam petridish. Kemudian dilakukan pengambilan spektrum pada bubuk biji kakao dengan menggunakan alat FT-IR IPTEK T-1516.

\section{Pengambilan Spektrum Bubuk Biji Kakao}

Kalibrasi background/reference dilakukan tiap jam. Proses bekerjanya alat menggunakan integrating sphere. Pengendalian kerja alat untuk pembuatan workflow dan menjalankan workflow menggunakan software termo intregation ${ }^{\circledR}$ dan untuk running alat dilakukan oleh termo operation ${ }^{\circledR}$. Selang panjang gelombang yang dipilih adalah antara 1000-2500 nm dengan interval $0.4 \mathrm{~nm}$. Workflow dibuat untuk mengatur alat agar bekerja untuk mengakuisisi spektrum absorban, memindai sampel sebanyak 64 kali perproses lalu merata-ratakan hasilnya, menyimpan hasil pemindaian dalam 3 bentuk file yakni *.SPA. *.JDX dan *.CSV. Selanjutnya dilakukan pengukuran kadar lemak dengan menggunakan metode soxhlet. Data absorban diperoleh dengan cara menstransformasikan nilai reflektan/pantulan kedalam bentuk Log (1/R). Pretreatmentyang digunakan adalah Baseline Shift dan Derivatif-2. Model prediksi dibangun menggunakan Partial Least Square (PLS) untuk menduga kadar lemak bubuk biji kakao. 


\section{Prosedur Pengujian di Laboratorium Kadar lemak}

Pengukuran kadar lemak menggunakan Metode Soxhlet( Zulfahrizal, 2014). Prosedur pengukuran dimulai dengan mengeringkan labu takar bersama beberapa batu api selama 1 jam pada suhu $105^{\circ} \mathrm{C}$. Lalu didinginkan dalam exicator. Kemudian ditimbang, hasilnya dicatat sebagai sebagai nilai L. Sampel sebanyak 10 gram dimasukkan dalam extraction thimble kemudian ditutup dengan kapas dan extraction thimble ditempatkan dalam perangkat soxhlet. Selanjutnya menambahkan 100-150 $\mathrm{ml}$ n-hexana ke dalam labu takar. Maka proses ekstraksi dapat dimulai. Ekstraksi dilakukan selama 6 jam pada suhu $95^{\circ} \mathrm{C}$ sampai $n$-hexana bersih. Selanjutnya $n$-hexana diuapkan dengan rotary evaporator sampai yang tertinggal adalah cairan lemak. Lalu labu takar yang mengandung lemak dikeringkan dalam oven pada suhu $105^{\circ} \mathrm{C}$ selama 30 menit. Terakhir, labu takar didinginkan di dalam exicator. Setelah dingin, labu takar ditimbang kembali dan dicatat sebagai LA.

$$
\mathrm{KL}(\%)=\frac{(L A-L) \times 10.000}{10 \times \text { material kering }(\%)}
$$

Dimana :

L : Berat awal labu takar (gr)

LA : Berat akhir labu takar (gr)

\section{Pengembangan danPengujian Model Kalibrasi}

Keseluruhan data dipakai sebagai dataset kalibrasi yang digunakan untuk membangun model prediksi kadar lemak. Kemudian dilakukan validasi silang ( -fold cross validation) dengan jumlah segment adalah(fold) 10.

Model prediksi dibangun dengan menggunakan metode Partial Least Square (PLS). Evaluasi keakuratan dan kehandalan model dievaluasi dengan melihat parameter statistik yang meliputi: koefisien kolerasi (r), koefisien determinasi $\left(\mathrm{R}^{2}\right)$, residual predictive index (RPD), root mean square error cross validation(RMSECV), root mean square error calibration (RMSEC), dRMSE dan Latent Variable (LVs). Model persamaan kalibrasi data serapan dibandingkan dengan data aktual dan dilihat nilai $r, \mathrm{R}^{2}$, RMSEC, RMSECV, dRMSE, RPD dan LVs. Model yang bagus memiliki nilai $r>0,6, \mathrm{R}^{2}$ yang tinggi, RMSEC, RMSECV, dRMSE yang rendah, RPD $>1,5$, jumlah latent variable $<9$; RMSEC, dRMSE dan RPD dicari dengan persamaan ( Zulfahrizal, 2013 ; Florez, 2009 ; Jha, 2006 ; Nicolai, 2007 ) :

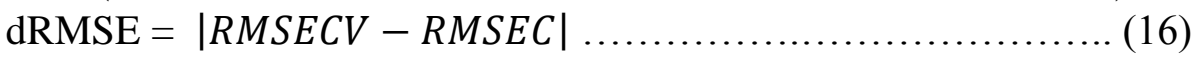

$$
\begin{aligned}
& R M S E C, R M S E C V=\sqrt{\frac{1}{n} \sum_{i=1}^{n}\left(\hat{y}_{i}-y_{i}\right)} \\
& R P D=\frac{\mathrm{SD}}{R M S E C V} \\
& \text { Dimana : } \\
& \hat{y}_{I}=\text { parameter nilai dari dugaan awal model sampel ke-i. } \\
& \mathrm{y}_{\mathrm{i}}=\text { parameter nilai hasil pengukuran laboratorium untuk sampel ke-i } \\
& \mathrm{n}=\text { jumlah sampel dalam kalibrasi atau validasi. } \\
& \mathrm{SD}=\text { standar deviasi untuk data prediksi. }
\end{aligned}
$$

\section{HASIL DAN PEMBAHASAN Tipikal Spektrum}


Pengukuran spektra yang digunakan pada rentang panjang gelombang 1000-2500 nm dengan interval $0.4 \mathrm{~mm}$ sebanyak 30 sampel. Selang panjang gelombang dibawah $1000 \mathrm{~nm}$ sengaja dipotong karena cenderung tidak memberikan informasi yang dibutuhkan. Pada panjang gelombang 1000-2500 nm memperlihatkan spektrum dengan beberapa puncak-puncak yang terbentuk. Puncak spektrum NIR ini dipengaruhi oleh komponen kimia didalam bahan dan karakter fisik bahan. Masing-masing puncak dapat diinterpretasikan memiliki kandungan kimia yang berbeda. Spektrum bubuk biji kakao yang didapat dari pengukuran spektra dengan alat NIRS dapat dilihat berdasarkan Gambar 1 pada a. Raw Spektrum.

Selanjutnya terlihat jelas pada b. Baseline shift (Gambar 1.) memberikan pengaruh yang berbeda terhadap spektra aslinya. Baseline shift dapat mengkoreksi bagian dasar spektrum dibandingkan dengan non pretreatment. Baseline Shift juga mampu memperbaiki dan menghilangkan interference gelombang elektromagnetik, ukuran partikel dan perubahan cahaya.

Berikutnya pada c. Derivatif-2 (Gambar 1.) Digunakan untuk menghilangkan background dan meningkatkan resolusi spektrum. Derivatifmampu memperjelas puncak dan lembah spektra absorban data NIRS.
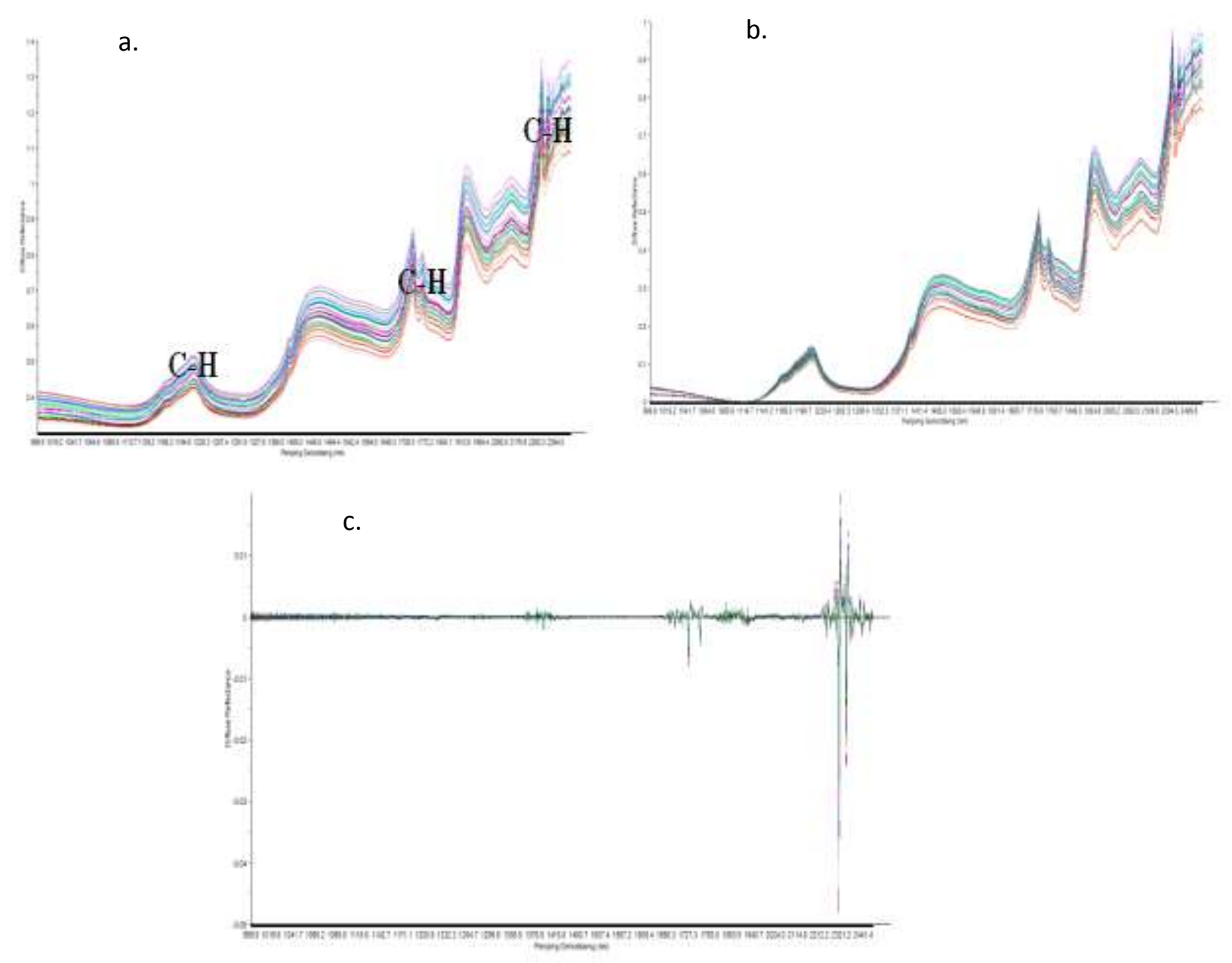

Gambar 1. Spektrum NIRS pada Bubuk Biji Kakao a. Raw Spektrum b. Baseline Shift c. Derivatif-2

\section{Loading Plot Spektrum}


Berdasarkan Gambar 2. salah satu sampel bubuk biji kakao diambil spektrumnya untuk mempermudah dalam interpretasi spektrum. Letak kandungan kadar lemak bubuk biji kakao berada pada panjang gelombang 1200-1220 nm, 1700-1740 nm, dan 2300-2400 nm. Rentang panjang gelombang ini mirip seperti yang didapat pada penelitian Zulfahrizal (2014) untuk biji kakao utuh, letak kandungan kadar lemak berada pada panjang gelombang 1160-1220 nm, 1650-1760 nm, 2300-2400 nm. Namun pada penelitian ini puncak yang menandakan keberadaan kadar lemak tampak lebih jelas, hal ini terjadi karena pengurangan kadar air pada saat pembubukan.Ternyata dapat disimpulkan bahwa kandungan kadar lemak pada biji kakao maupun bubuk biji kakao mempunyai tipikal spektrum yang sama.

Berdasarkan Gambar 3. pada a. Dimana pada Baseline Shift getaran yang terjadi pada panjang gelombang 1180-1220 nm, 1650-1780 nm, dan 2300-2400 nm menunjukkan adanya ikatan C-H (penanda keberadaan kadar lemak). Panjang gelombang 2300-2400 nm merupakan panjang gelombang yang paling relevan pada baseline shift ditandai dengan terjadinya stretching pada panjang gelombang tersebut, sehingga dapat disimpulkan bahwa pada panjang gelombang tersebut dapat mencirikan secara khas kandungan kadar lemak pada bubuk biji kakao.

Selanjutnya pada b. Derivatif-2 (Gambar 3). Menunjukkan loading plot derivatif-2 terlihat adanya puncak-puncak yang menandakan kandungan kimia kadar lemak dari bubuk biji kakao. Getaran yang terjadi pada panjang gelombang 1700-1760 nm, dan 2300-2400 nm menunjukkan adanya ikatan C-H (penanda keberadaan kadar lemak). Panjang gelombang 2300$2400 \mathrm{~nm}$ merupakan panjang gelombang yang paling relevan sehingga dapat disimpulkan bahwa pada panjang gelombang tersebut yang dapat mencirikan secara khas kandungan kadar lemak pada bubuk biji kakao.

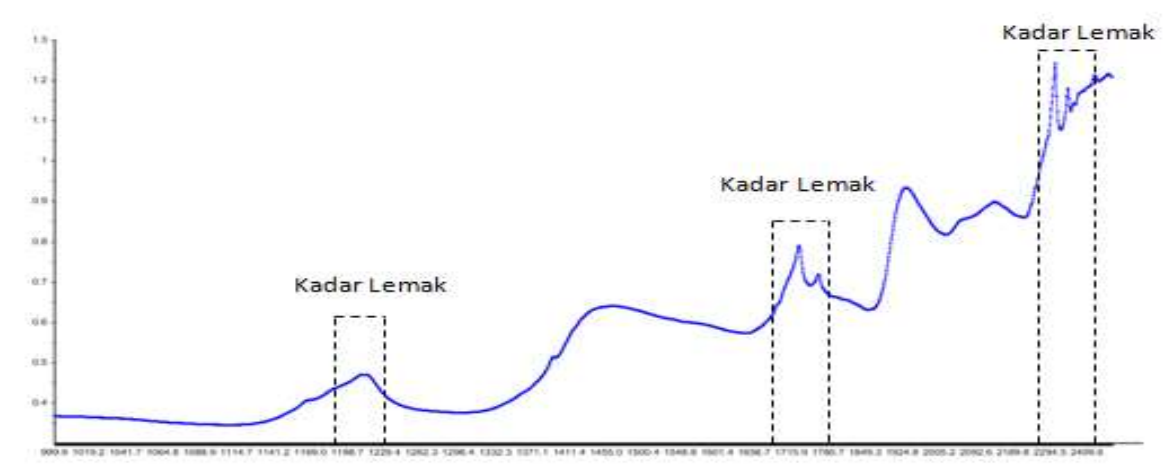

Gambar 2. Letak Kadar Lemak Pada Spektrum Bubuk Biji Kakao non Pretreatment
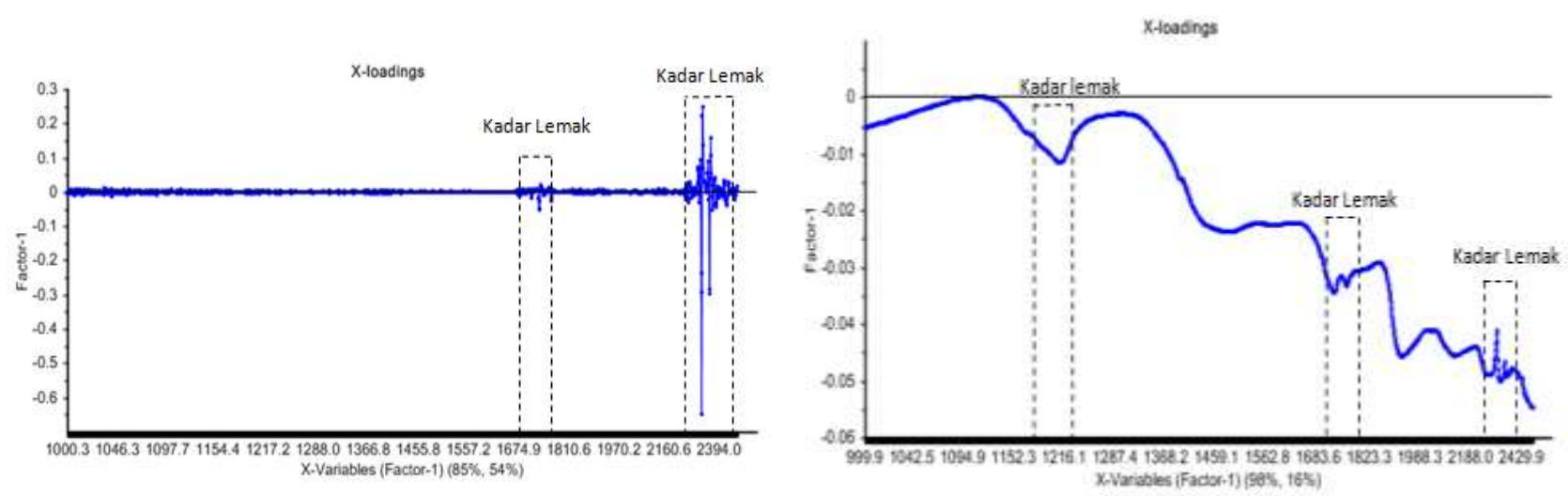

Gambar 3. Loading Plot untuk Pretreatment a. Baseline Shift b. Derivatif-2 


\section{Kalibrasi dan Validasi Silang \\ Kalibrasi}

Hasil pendugaan pada tahap kalibrasi nonpretreatment memperlihatkan nilai koefisien korelasi (r) yaitu 0,93. Menurut William dan Norris (1990) menyatakan nilai $r$ diatas 0,90 dianggap sudah baik. Koefisien determinasi $\left(\mathrm{R}^{2}\right)$ yaitu 0,87 . Menurut Karouiet al. (2006)nilai $\left(\mathrm{R}^{2}\right)$ yang berada pada selang 0,82-0,90 menyatakan prediksi yang baik. Sementara nilai error (RMSEC) yaitu 0,79. Menurut William dan Norris (1990) sebaiknya kecil dari standar deviasi data aktual dianggap sudah baik. Serta nilai latent variablesebesar 4. Plot data kalibrasi non pretreatment dapat dilihat pada Gambar 14.

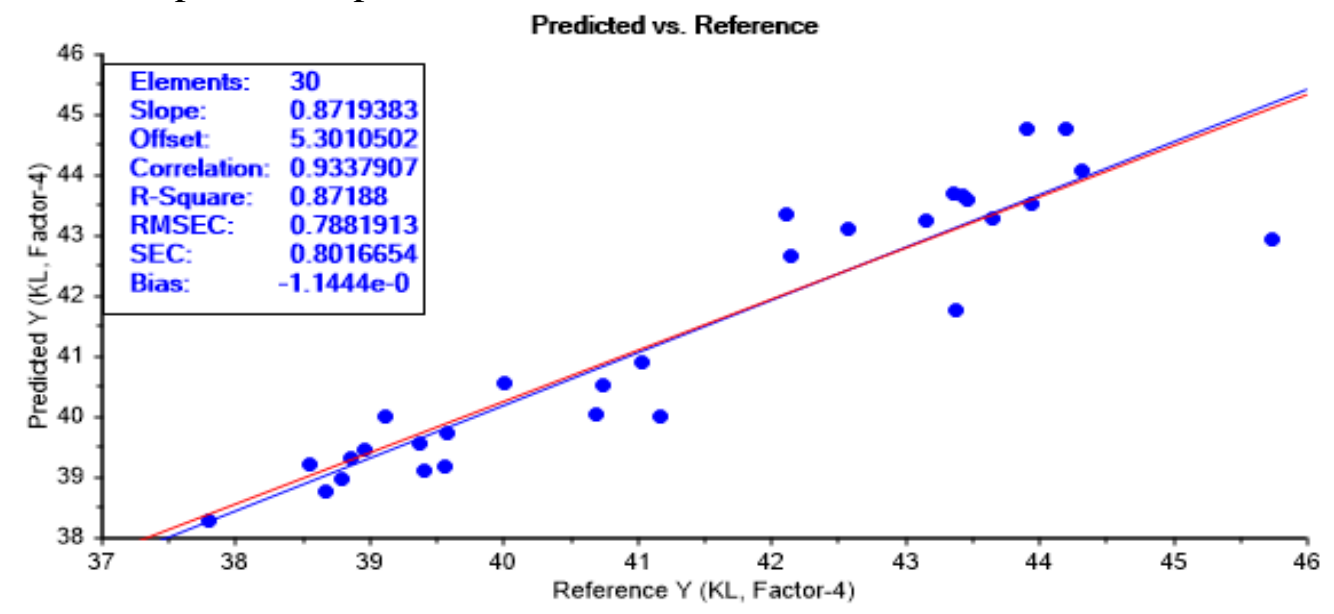

\section{Gambar 14. Plot Data Kalibrasi Non Pretreatment}

Pemakaian pretreatment baseline shift kurang mampu meningkatkan kinerja PLS hasil pendugaan seperti yang terlihat pada Gambar 15. Hal ini dilihat dari nilai koefisien korelasi (r), nilai koefisien determinasi $\left(\mathrm{R}^{2}\right)$, yang sama dengan non pretreatmentdan nilai error (RMSEC) yaitu 0,78. Menurut William dan Norris (1990) sebaiknya kecil dari standar deviasi data aktual dianggap sudah baik. Namun baseline shift mampu mengurangi jumlah latent variable menjadi 3 latent variable. Plot data kalibrasi BS + PLS dapat dilihat pada Gambar 14.

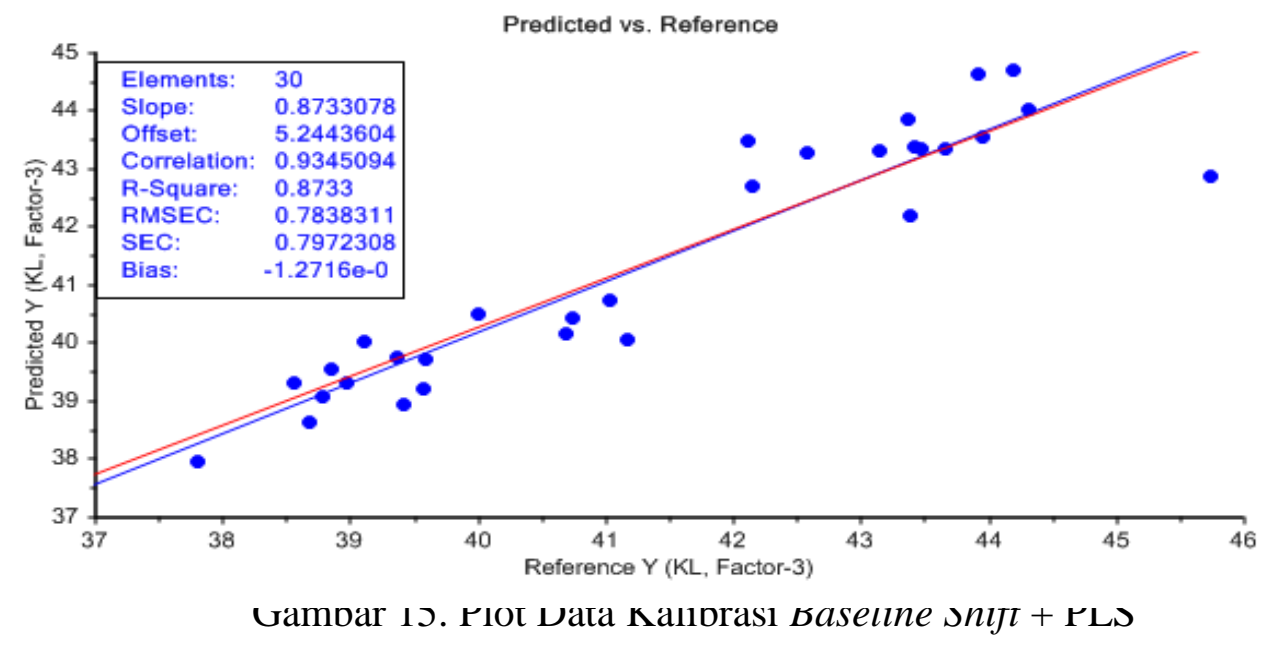

Pemakaian pretreatment derivatif-2 mampu meningkatkan kinerja PLS hasil pendugaan seperti yang terlihat pada Gambar 16. Hal ini dilihat dari nilai koefisien korelasi (r) yang meningkat menjadi 0,96. Menurut William dan Norris (1990) menyatakan nilai $r$ diatas 0,90 
dianggap sudah baik. Nilai koefisien determinasi $\left(\mathrm{R}^{2}\right)$ meningkat menjadi 0,92 . Menurut Karouiet al. (2006)menyatakan nilai $\left(\mathrm{R}^{2}\right)$ diatas 0,91 menyatakan dugaan sangat baik. Nilai error(RMSEC) yaitu 0,61. Menurut William dan Norris (1990) sebaiknya kecil dari standar deviasi data aktual dianggap sudah baik. Serta latent variable yaitu 3 latent variable.

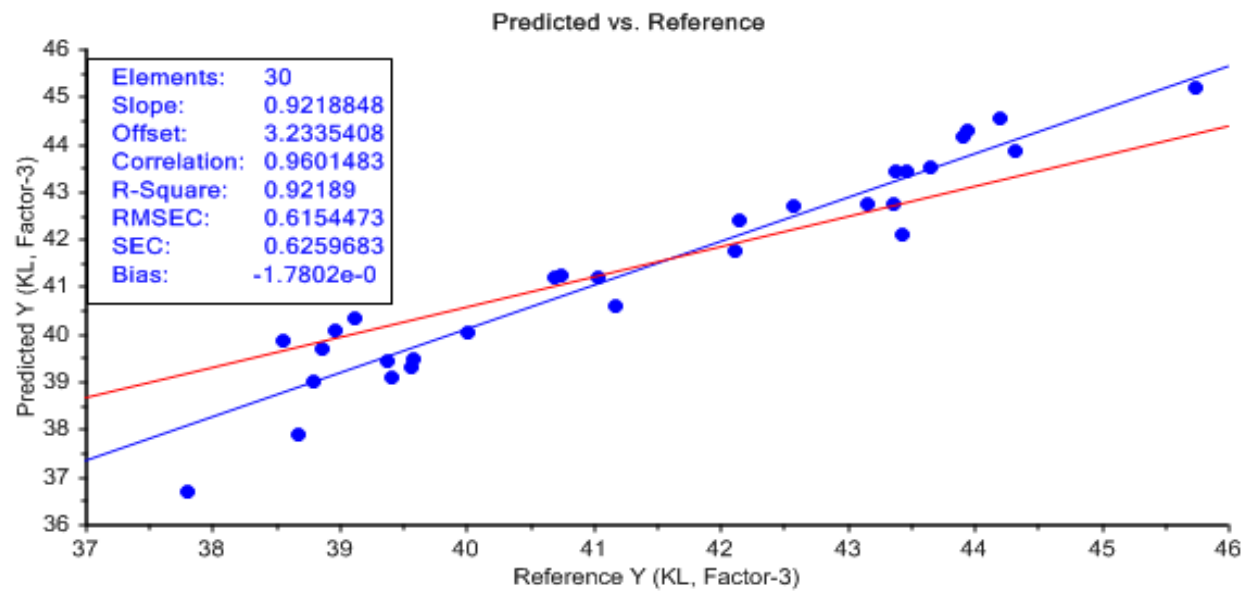

Gambar 16. Plot Data Kalibrasi Derivatif-2 + PLS

Selanjutnya jika ditinjau dari segi efesiensipretreatment baseline shiftdan Derivatif-2 dapat dikatakan paling efisien jika dilihat dari pengurangan jumlah laten variable menjadi 3. Semakin sedikit latent variable maka dikatakan hasil pendugaan makin efisien.

Tabel8. Hasil Kalibrasi Kadar Lemak Bubuk Biji Kakao

\begin{tabular}{lcccc}
\hline Perlakuan & Latent variable & $\mathrm{r}$ & $\mathrm{R}^{2}$ & $\begin{array}{c}\text { RMSEC } \\
(\%)\end{array}$ \\
\hline Non pretreatment & 4 & 0,93 & 0,87 & 0,79 \\
Baseline Shift & 3 & 0,93 & 0,87 & 0,78 \\
Derivatif-2 & 3 & 0,96 & 0,92 & 0,61 \\
\hline
\end{tabular}

\section{Cross Validation (validasi silang)}

Hasil pendugaan validasi silang non pretreatment menghasilkan nilai koefisien korelasi (r) yaitu 0,90. Menurut William dan Norris (1990) menyatakan nilai $\mathrm{r}$ diatas 0,90 dianggap sudah baik. Koefisien determinasi $\left(\mathrm{R}^{2}\right)$ yang cukup bagus yaitu 0,82 . Menurut Karouiet al. (2006)nilai $\left(\mathrm{R}^{2}\right)$ yang berada pada selang 0,82-0,90 menyatakan prediksi yang baik. Nilai error (RMSECV) yaitu 0,96. Menurut William dan Norris (1990) sebaiknya kecil dari standar deviasi data aktual dianggap sudah baik. Nilai dRMSE sebesar 0,18. Sementara dan nilai RPD yang bagus yaitu sebesar 2,33. Menurut Nicolai et al. (2007) nilai RPD yang berada dalam selang 2 -2,5menandakan bahwa model itu termasuk good model performance. Plot data validasi silang non pretreatment dapat dilihat pada Gambar 17. 

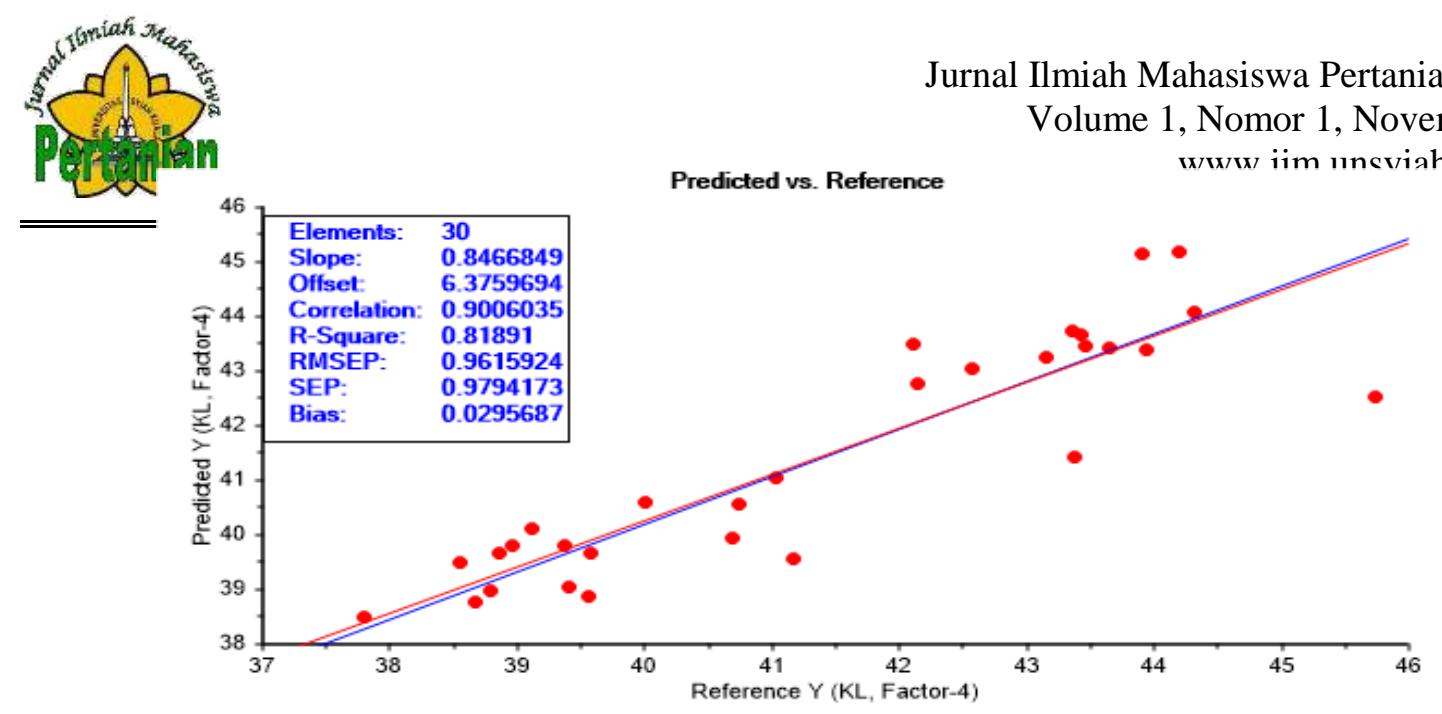

Gambar 17. Plot Data Validasi Silang Non Pretreatment

Pemakaian pretreatment baseline shift dapat meningkatkan kinerja PLS hasil pendugaan keakuratan model yang dibangun seperti yang terlihat pada Gambar 18. Hal ini bisa dilihat dari nilai koefisien korelasi (r) yang meningkat menjadi 0,91. Menurut William dan Norris (1990) menyatakan nilai $r$ diatas 0,90 dianggap sudah baik. Nilai koefisien determinasi $\left(R^{2}\right)$ yang meningkat menjadi 0,84.Menurut Karouiet al. (2006)nilai $\left(\mathrm{R}^{2}\right)$ yang berada pada selang0,820,90 menyatakan prediksi yang baik.Nilai error (RMSECV) yaitu 0,90. Menurut William dan Norris (1990) sebaiknya kecil dari standar deviasi data aktual dianggap sudah baik. Nilai dRMSE yang bagus yaitu sebesar 0,12 , selanjutnya jika dilihat dari nilai RPD, ternyata masih diatas dua yaitu 2,48 tergolong good model performance. Menurut Nicolai et al. (2007) nilai RPD yang berada pada selang $2-2,5$ menandakan bahwa model itu termasuk good model performance.

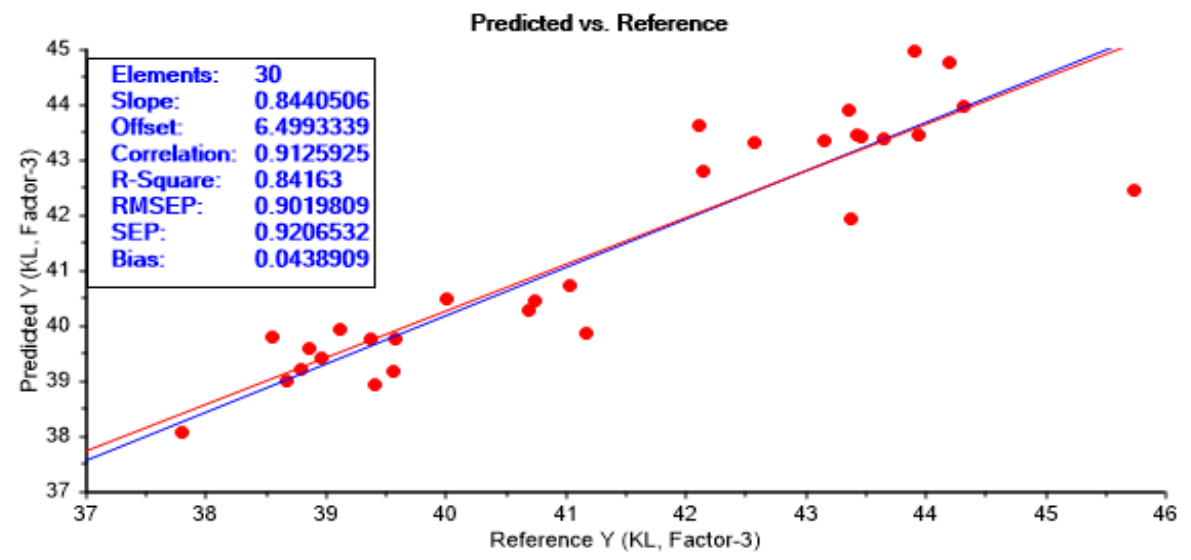

Gambar 18. Plot Data Validasi Silang Baseline Shift + PLS

Pemberian pretreatment Derivatif-2 kurang mampu meningkatkan kinerja PLS hasil pendugaan keakuratan model yang dibangun seperti yang terlihat pada Gambar 19. Hal ini bisa dilihat dari nilai koefisien korelasi (r) yaitu 0,78. Menurut William dan Norris (1990) menyatakan nilai $\mathrm{r}$ sebaiknya mendekati 1 diatas 0,90 dianggap sudah baik. Nilai koefisien determinasi $\left(\mathrm{R}^{2}\right)$ yaitu 0,62 . Menurut Karoui et al. (2006) nilai $\left(\mathrm{R}^{2}\right)$ Lebih dari $50 \%$ variable $\mathrm{Y}$ dipengaruhi oleh variable X. Selanjutnya nilai error (RMSECV) data yaitu 1,37. Menurut William dan Norris (1990) sebaiknya kecil dari standar deviasi data aktual dianggap sudah baik. Nilai dRMSE yang bagus yaitu sebesar 0,76dan jika dilihat dari nilai RPD yaitu 1,63 tergolong Sufficient performance. Menurut Nicolai et al. (2007) nilai RPD yang berada dalam selang 1,5 - 1,9 menunjukkan prediksi masih kasar dan perlu perbaikan. 


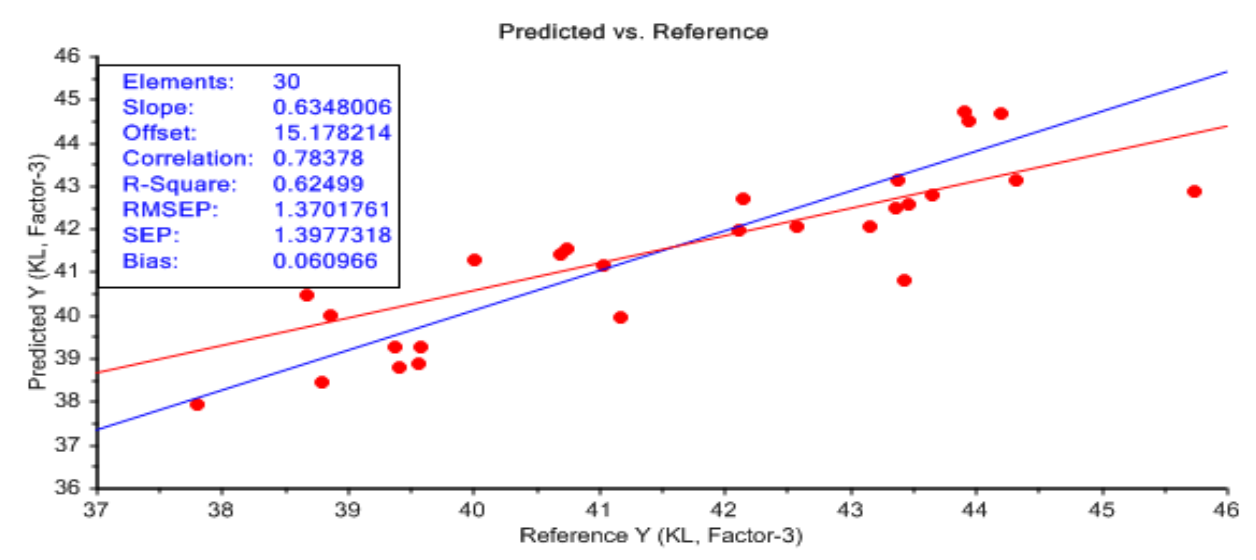

Gambar 19. Plot Data Validasi Silang Derivatif-2 + PLS

Tabel 9. Hasil Validasi Silang Kadar Lemak Bubuk Biji Kakao

\begin{tabular}{lccccc}
\hline Perlakuan & $\mathrm{r}$ & $\mathrm{R}^{2}$ & $\begin{array}{c}\text { RMSECV } \\
(\%)\end{array}$ & dRMSE & RPD \\
\hline Non pretreatment & 0,90 & 0,81 & 0,96 & 0,18 & 2,33 \\
Baseline Shift & 0,91 & 0,84 & 0,90 & 0,12 & 2,48 \\
Derivatif-2 & 0,78 & 0,62 & 1,37 & 0,76 & 1,63 \\
\hline
\end{tabular}

Kemampuan PLS dalam menduga kadar lemak pada bubuk biji kakao dapat dikatakan bagus dilihat dari hasil validasi silang. Pemberian PLS tanpa pretreatment masih menghasilkan model yang tergolong good model performance walaupun nilai $r$ hasil validasi silang berkurang 3,22\% dari kalibrasi, nilai dRMSE sebesar 0,18 serta nilai RPD 2,33. Kemudian pemberian PLS dengan penambahan pretreatmentbaseline shift juga menghasilkan model yang tergolong good model performancewalaupun nilai $\mathrm{r}$ hasil validasi silang berkurang sebesar $2,15 \%$ dari kalibrasi, nilai dRMSE sebesar 0,12 dan nilai RPD yaitu 2,48. selanjutnya pemberian PLS dengan penambahan pretreatment derivatif-2menghasilkan model yang tergolong sufficient performance, nilai $\mathrm{r}$ hasil validasi silang berkurang sebesar $23,07 \%$, serta nilai dRMSE berkurang sebesar 0,76 dan nilai RPD yaitu 1,63. Sehingga dapat disimpulakan bahwa pretreatment yang dapat meningkatkan performa PLS hasil pendugaan adalah baseline shift dilihat dari nilai RPD yaitu 2,48 yang tergolong good model performance.

\section{KESIMPULAN DAN SARAN}

Panjang gelombang 2300-2400 $\mathrm{nm}$ merupakan panjang gelombang yang relevan dalam menduga kadar lemak pada bubuk biji kakao.Penambahan PLS dengan penambahan pretreatment baseline shift menghasilkan model yang tergolong good model performance dan dengan pretreatment Derivatif-2 menghasilkan model yang tergolong sufficient performance.Pretreatment yang paling baik dalam meningkatkan performa PLS hasil pendugaan adalah baseline shift dilihat dari nilai RPD yaitu 2,48 yang tergolong good model performance.Pretreatment baseline shift dan Derivatif-2 dapat dikatakan paling efisien jika dilihat dari pengurangan jumlah latent variable yang menjadi 3 latent variable. 


\section{DAFTAR PUSTAKA}

Badan Pusat Statistik Aceh. 2013.Aceh Dalam Angka.Aceh.

[BSN] Badan Standarisasi Nasional. 2008. Parameter Mutu dan Pengukuran Standarisasi kakao dan Kopi.

CAMO, 2012. Method Reference the Uscrambler x10.2.

Cen, H dan Y.He. 2007. Theory and Application of Near Inrfrared Reflectance Spectroscopy in Determination of Food Quality. J. Trends in Food Sci \& Technol 18: 72-83.

Florez, K., M. T.Sanchez, D.Perez-Marin, J. E.Guerrero, A.G. Varo. 2009. Feasibility in NIRS Instrument for Predicting Internal Quality in Intact Tomato. J. Food Engineering. 91: 311-318

International Cocoa Organization. 2015. ICCO Quarterly of Cocoa Statistic.

Jha, S. N., A.R.P. Kingsly, S.Chopra. 2006. Non-Destruktif Determination of Firmness and Yellowness of Mango During Growth and Storage Using Visual Spectroscopy. J. Biosystem Engineering. 94: 397-402.

Karoui R., A. M. Mouazena, E. Dufourb, L. Pillonelc, E. Schallerd, J. De Baerdemaekera, Dan J. O. Bossetc. 2006. Chemical Characterisation Of European Emmental Cheeses By Near Infrared Spectroscopy Using Chemometric Tools. International Dairy Journal. 16: 1211-1217.

Mulato, S., S.Widyotomo, Miswani, E.Suharyanto. 2009. Pengolahan Produk Primer dan Sekunder Kakao. Pusat Penelitian Kopi dan Kakao Indonesia. Jember.

Nicolai, B. M., K. Beullens, E. Bobelyn, A.Peirs, W.Saeys, K. I.Theron, J.Lamertyn. 2007. Nondestructive Measurement of Fruit and Vegetable Quality by Means of NIR Spectroscopy : A Review. Postharvest Biology and Technology. 46: 99-118.

William P., K.Norris. 1990. Near Infrared Technology in the Agricultural anf Food Industries. Ed ke-2. Minnesota (USA): Amerika Association of Cereal Chemists Inc.

Zulfahrizal, Sutrisno,IW. Budiastra,K. B. Seminar, A. A. Munawar. 2013. Akuisisi Spektrum Near Infrared Reflectance pada Biji Kakao.Bul. Riset Tanaman Rempah dan Aneka Tanaman Industri, 4, 1-10.

Zulfahrizal. 2014. Pengembangan Metode Pengukuran Nondestruktif Untuk Menentukan Mutu dan Fermentasi Biji Kakao Utuh Menggunakan Nir Spectroscopy [ Disertasi ]. Institut Pertanian Bogor .Bogor . 